\title{
Isolation and efficacy of the endophytic fungus, Beauveria bassiana (Bals.) Vuillemin on grapevine aphid, Aphis illinoisensis Shimer (Hemiptera: Aphididae) under laboratory conditions
}

\author{
Samy Sayed ${ }^{1,2,3^{*}}$, Ahmed El-Shehawi ${ }^{1,4}$, Saad Al-Otaibi ${ }^{1}$, Samir El-Shazly ${ }^{1,5}$, Saqer Al-Otaibi ${ }^{1}$, Reda Ibrahim ${ }^{5,6}$, \\ Mohammed Alorabi ${ }^{1}$, Alaa Baazeem ${ }^{7}$ and Mona Elseehy ${ }^{4}$
}

\begin{abstract}
The endophytic fungus, Beauveria bassiana has been found to occur endophytically in hundreds of plant species tissues and has been inoculated for establishment in different plants. It has negative effect on piercing-sucking insects in grapevine plants. Thus, the present study aimed to detect the endophytic fungus, B. bassiana throughout ITS genes analysis in the grapevine plant, Vitis venifera cv. Taify and assess its potential for controlling the grapevine aphid, Aphis illinoisensis Shimer (Hemiptera: Aphididae). The obtained 5 isolates were DNA sequenced for ITS region. Data analysis showed that there were 2 different isolates (accession number: MN900613 for isolate Bb-Taif1 and MN900614 for isolate Bb-Taif2). The values of $\mathrm{LC}_{50}$ were $6.041 \times 10^{4}, 3.199 \times 10^{5}$ spores $/ \mathrm{ml}$ while those of $\mathrm{LC}_{90}$ were $6.13 \times 10^{6}$ and $7.474 \times 10^{7}$ spores $/ \mathrm{ml}$ after 3 days of treatment by Bb-Taif1 and Bb-Taif2, respectively. These values showed that the virulence of Bb-Taif1 isolate was higher in its efficacy than the Bb-Taif2 isolate. Further investigations are needed to evaluate its efficacy on other piercing sucking or chewing insect pests throughout conidia spraying, soil inoculation, and/or root immersion for grapevine plants.
\end{abstract}

Keywords: Endophytic fungi, Grapevine, Beauveria bassiana, Identification, ITS genes, Aphis illinoisensis, Bioassay

\section{Background}

The fungal endophytes (living within plant tissues) play important roles in plant community ecology (Wani et al. 2015). The study of endophytic microorganisms is defined as "endophytology" (Unterseher et al. 2012). They are called endophytes because they colonize the healthy plant tissues in some periods of their life cycle without causing damage for the plants (Azevedo et al. 2000). The

\footnotetext{
*Correspondence: samy_mahmoud@hotmail.com

'Department of Biotechnology, Faculty of Science, Taif University, Taif 888, Saudi Arabia

${ }^{2}$ Department of Economic Entomology and Pesticides, Faculty of Agriculture, Cairo University, Giza 12613, Egypt

Full list of author information is available at the end of the article
}

distinction between pathogenic and endophytic microorganisms depends on the stage of the interaction of the microorganism with the host plant (Strobel et al. 2004). Many authors have proposed that the studies of endophytic fungi can be called "endophytism" (Suryanarayanan 2013), and others define these fungi as "mycoendophytes" (Rai et al. 2014). These endophytic fungi have negative effects on different insect pests and plant pathogens by producing toxic compounds or by modifying the host plant defense response to enable pest and pathogen resistance (Backman and Sikora 2008; Saikkonen et al. 2010). There are different beneficial effects of these endophytic fungi on host plants as plant growth promoting, increasing and induction of plant defense mechanisms, disease severity 
reduction, and producing of different anti-herbivore products (Yang et al. 2016).

The important group of endophytic microorganisms is the entomopathogenic fungi of the order Hypocreales, known to cause infections in insects. Beauveria spp. are common terrestrial entomopathogens, infecting numerous insect and arachnid taxa in various regions of the world (Vega 2008). Beauveria bassiana has been recognized to occur endophytically in hundreds of species in plant tissues and has been inoculated for establishment in different valuable crops and vegetable plants (Vega 2008; Vidal and Jaber 2015; and Gonzalez et al. 2016). The lethal effect of these endophytic fungi on insects is shown by eating the plant parts in chewing insects or by oral ingestion of plant sap in sucking insects (Batta 2018).

Thus, there is much interest in how to detect and use endophytic fungi specially Beauveria and Metarhizium with insect pathogenic capabilities to induce plant tolerance to insect pests (Vega 2008). These fungi are globally distributed and commercially available as biological control agents (Lacey et al. 2015). Many investigations were carried out on the inoculation of 13 plant species belonging to 15 families with various entomopathogenic fungi such as $B$. bassiana. These studies have examined seed dressing, seed soaking, foliar sprays, mycosed insects placed in the soil, soil drenching, and fungal plugs placed in the soil (Vega 2018). However, the endophytic $B$. bassiana present in grapevine has negative effect on piercing-sucking insects, while it reduces infestation rate and growth of the vine mealy bug, Planococcus ficus (Signoret) in young plants and induces high reduction of infestation with grape leafhopper, Empoasca vitis (Goethe) (Rondot and Reineke 2018).

Till now, there is no negative impact of the presence of endophytic $B$. bassiana on various host plants in a range of investigations (Zimmermann 2007; Klieber and Reineke 2016). Endophytic B. bassiana has been reported for maintaining systemic protection against various piercing-sucking insect pests or for inhibiting insect development (Rondot and Reineke 2018). Moreover, presence of endophytic $B$. bassiana reduces disease symptoms induced by various fungal pathogens (Cosoveanu et al. 2014; Jaber 2015).

The detection and identification of endophytic fungi is important to determine their distribution in host plants and their beneficial effects. Detection of endophytic microorganisms is characteristically attained through various techniques, including isolation of fungal material directly from plant tissues to growth media (culturedependent), microscopy, and molecular recognition of endophytic DNA from different plant materials, using PCR (culture-independent) (McKinnon et al. 2017). Another recent technique is the fluorescence microscopy, which can be used to detect endophytes inside plant tissues (Pacifico et al. 2019). In general, the internal transcribed spacer-1 (ITS1), the internal transcribed spacer-2 (ITS2), and 5.8 $\mathrm{S}$ regions of the nuclear ribosomal DNA are commonly utilized for molecular identification of B. bassiana (Mondal and Baksi 2018).

Grapevine (Vitis vinifera L. cv. Taify) is the second most important economical fruit in Saudi Arabia and it is consumed as table grapes, grape juice, or raisins. This cultivar has been reported as the best quality for chemical composition comparing to other cultivars cultivated in Saudi Arabia (Fahmi et al. 2012). The grapevine trees are infested with different insect pests such as lepidopterous insects, mealy bugs, leafhopper, thrips, scale insects, and aphids. The grapevine aphid, Aphis illinoisensis (Shimer) is a grapevine pest infesting young terminal shoots, the lower surface of young leaves (Blackman and Eastop 2006) and fruit clusters causing drops of some grape berries (Pfeiffer and Schultz 1986). It is one of such invasive species recorded since the 2000s in Southern Europe and in the North African countries (El-Gantiry et al. 2012).

The present study aimed to detect and assess the potential of endophytic fungus, $B$. bassiana in the grapevine, $V$. venifera cv. Taify for controlling the grapevine aphid, and A. illinoisensis under laboratory conditions.

\section{Material and methods}

Sample collection and plant material

Healthy leaves from 3-year-old grapevine plants (Vitis venifera cv. "Taify"), cultivated in 2 locations at Taif, Saudi Arabia $\left[21^{\circ} 9^{\prime} \mathrm{N}, 40^{\circ} 35^{\prime} \mathrm{E}\right.$ (location-1), and $20^{\circ}$ $56^{\prime} \mathrm{N}, 40^{\circ} 49^{\prime} \mathrm{E}$ (location-2)], were collected approximately $1.5-2.0 \mathrm{~m}$ above the ground. Five leaves per plant (5 distant plants from each location) were sampled in September of 2019. To isolate B. bassiana endophytes, each plant leaf was washed with distilled water. Then, the surface was sterilized by immersion in $3 \%$ sodium hypochlorite for $4 \mathrm{~min}$, and rinsed twice in sterile distilled water for 1 min (Martini et al. 2009).

\section{Fungi isolation}

After sterilization of leaves surface, 3 leaf discs $(1 \mathrm{~cm}$ in diameter) were obtained from each leaf. Leaf discs were placed on selective medium of EPF (DOC2-PDA medium), which prepared as follow: $2 \mathrm{mg}$ crystal violet, $0.2 \mathrm{~g} \mathrm{CuCl}_{2}, 39 \mathrm{~g}$ Potato Dextrose Agar (PDA) dissolved in 1 liter distilled water, while $\mathrm{pH}$ was adjusted to 4.0 with $\mathrm{HCl}$ and autoclaved for $20 \mathrm{~min}$ at $120^{\circ} \mathrm{C}$ (Shin et al. 2010). Plates were incubated at $20^{\circ} \mathrm{C}$ with a $12: 12$ h light: dark photoperiod. After 10-14 days, leaf discs were examined visually for the presence of endophytic $B$. bassiana that grew from internal plant tissues of surface sterilized leaf discs with white dense mycelia and creamy color at the edge (Humber 1997). 


\section{Genomic DNA isolation}

For final detection of endophytic B. bassiana, mycelia samples were analyzed with molecular techniques. DNA was extracted from fungal tissues, using the fungi/yeast genomic DNA extraction mini Kit (Favorgen Biotech Corporation, Taiwan) according to the manufacturer's instructions. The extracted DNAs were stored at $-20{ }^{\circ} \mathrm{C}$ for using as templates for PCR.

\section{PCR for ITS region and sequencing}

The PCR amplification was carried out to amplify a partial region of ribosomal DNA (ITS) containing $18 \mathrm{~S}$ gene (partial sequence), internal transcribed spacer-1 (complete sequence), 5.8S gene (complete sequence), internal transcribed spacer-2 (complete sequence), and $28 \mathrm{~S}$ gene (partial sequence). The amplification was done using specific primers (F: 5-GGAAGTAAAAGTCGTAACAA-3 and R: 5-TCCTCGCTTATTGATATGA-3) (Sayed et al. 2018). PCR amplification was carried out in a final volume of $50 \mu \mathrm{l}$ by mixing $2 \mu \mathrm{l}$ of DNA with $1 \mu \mathrm{l}$ of each primer (10 pmol), $25 \mu \mathrm{l}$ of M7123 green master mix (Promega, USA), and $22 \mu \mathrm{l}$ autoclaved double distilled water. The conditions of PCR amplification were $3 \mathrm{~min}$ at $94{ }^{\circ} \mathrm{C}$ followed by 35 cycles of $40 \mathrm{~s}$ at $94{ }^{\circ} \mathrm{C}, 40 \mathrm{~s}$ at $52^{\circ} \mathrm{C}$, and $40 \mathrm{~s}$ at $72{ }^{\circ} \mathrm{C}$ with a final extension of $7 \mathrm{~min}$ at $72{ }^{\circ} \mathrm{C}$. PCR products were checked by electrophoresis on a $1.5 \%$ agarose gel. After electrophoresis, the PCR products were cut out, cleaned and purified by the use of BioFlux BioSpin Gel Extraction kit (Bioertechnology Co., Ltd), and sequenced using the same primers by an automated DNA sequencer (Macrogen, Korea). Then, each sequence was checked in comparison to the GenBank database of the NCBI website. Finally, the sequences were deposited in GenBank of the NCBI website.

\section{Bioassay}

\section{Insects and fungi isolates}

Fresh leaves of grapevine plants infested with the aphid, A. illinoisensis were harvested on the same experimental day from the vineyard at Taif. Both fungal isolates were prepared as suspensions in six concentrations of $1 \times 10^{4}$, $1 \times 10^{4}, 1 \times 10^{5}, 1 \times 10^{6}, 1 \times 10^{7}$, and $1 \times 10^{8}$ spores $/ \mathrm{ml}$. Then, $0.02 \%$ Tween 80 was added to each suspension for dispersing the conidia uniformly in the suspension (Selvaraj et al. 2012). The suspensions were vortexed for 5 min to obtain homogeneity in the suspension.

\section{Experimental method}

Five replicates (each contained 40 aphid individuals) with totally 200 aphid individuals were used for each concentration. For the bioassay, $1 \mu \mathrm{l}$ of every single concentration was dropped straight on the aphid body (Eidy et al. 2016). Every Petri dish was filled by a thick layer $(3-4 \mathrm{~mm})$ of agar $(0.1 \%)$. The individuals of adult aphid
( 1 day old) were carefully relocated by a fine camel hairbrush from the leaf of grapevine to Petri dishes. In the control, aphid adults were treated with $1 \mu$ of distilled water with Tween $80(0.02 \%)$ for each one. The plant leaves were changed daily with other fresh leaves for feeding aphids. The experiment was carried out at $(25 \pm$ $1{ }^{\circ} \mathrm{C}, 65-70 \% \mathrm{RH}$ and a photoperiod of $\left.16 \mathrm{~L}: 8 \mathrm{D}\right)$. The aphid mortality was checked daily till the 3rd day.

\section{Statistical analysis}

Abbott's formula (Abbott 1925) was used with the purpose of correcting the mortality data in the treatments with that in the control. The $\mathrm{LC}_{50}$ and $\mathrm{LC}_{90}$ values for both isolates were measured employing Probit analysis with the SPSS software program (SPSS 2015). The $\mathrm{LC}_{50}$ and $\mathrm{LC}_{90}$ values, $95 \%$ confidence intervals (lower bound and upper bound), slope, intercept, and chi square of both isolates were subjected to $t$ test with a $P=0.05$.

\section{Results and discussion}

Seventy-five leaf discs from each location were examined for detection of the endophytic B. bassiana. Some leaves had fungal growth (Fig. 1). All obtained mycelia having the same characteristics of $B$. bassiana were analyzed for ITS amplification with $B$. bassiana specific primers. Therefore, the endophytic $B$. bassiana was detected in 3 plant samples of location-1 and 2 plants of location-2, with a PCR product of $593 \mathrm{bp}$ (Fig. 2). The 5 products were sequenced and the sequences showed that the 3 specimens from location-1 were identical. Moreover, the sequences of the 2 specimens from location- 2 were also identical; meanwhile, they were differed than the specimens in location-1. Consequently, the 3 specimens from location-1 were considered as unique isolate and were named as Bb-Taif1, while the 2 specimens from location-2 were considered as the second isolate and were named as Bb-Taif2. The alignment of ITS sequences for both isolates resulted in identity of $99 \%$. In this way, less geographical distances were related with less genetic variability where the isolation by distance of B. bassiana assumes a significant role in its genetic variation (Rehner et al. 2006). The differences between both isolate were in 5 nucleotides as follows: 2 nucleotides in the ITS1 and 3 in the ITS2 (Fig. 3). These 2 sequences were submitted in the NCBI GenBank database with the accession numbers of MN900613 for isolate Bb-Taif1 and MN900614 for isolate Bb-Taif2. In this sense, isolate $\mathrm{Bb}$-Taif1 was identical in the sequence of ITS with previous isolate (accession number: LC338054), which isolated from the soil at the same location (Sayed et al. 2018). In our opinion, this finding means that the same isolate in the soil was colonized in the grapevine plants. This suggestion is in accordance with other investigations, while soil inoculation was used for endophytic 

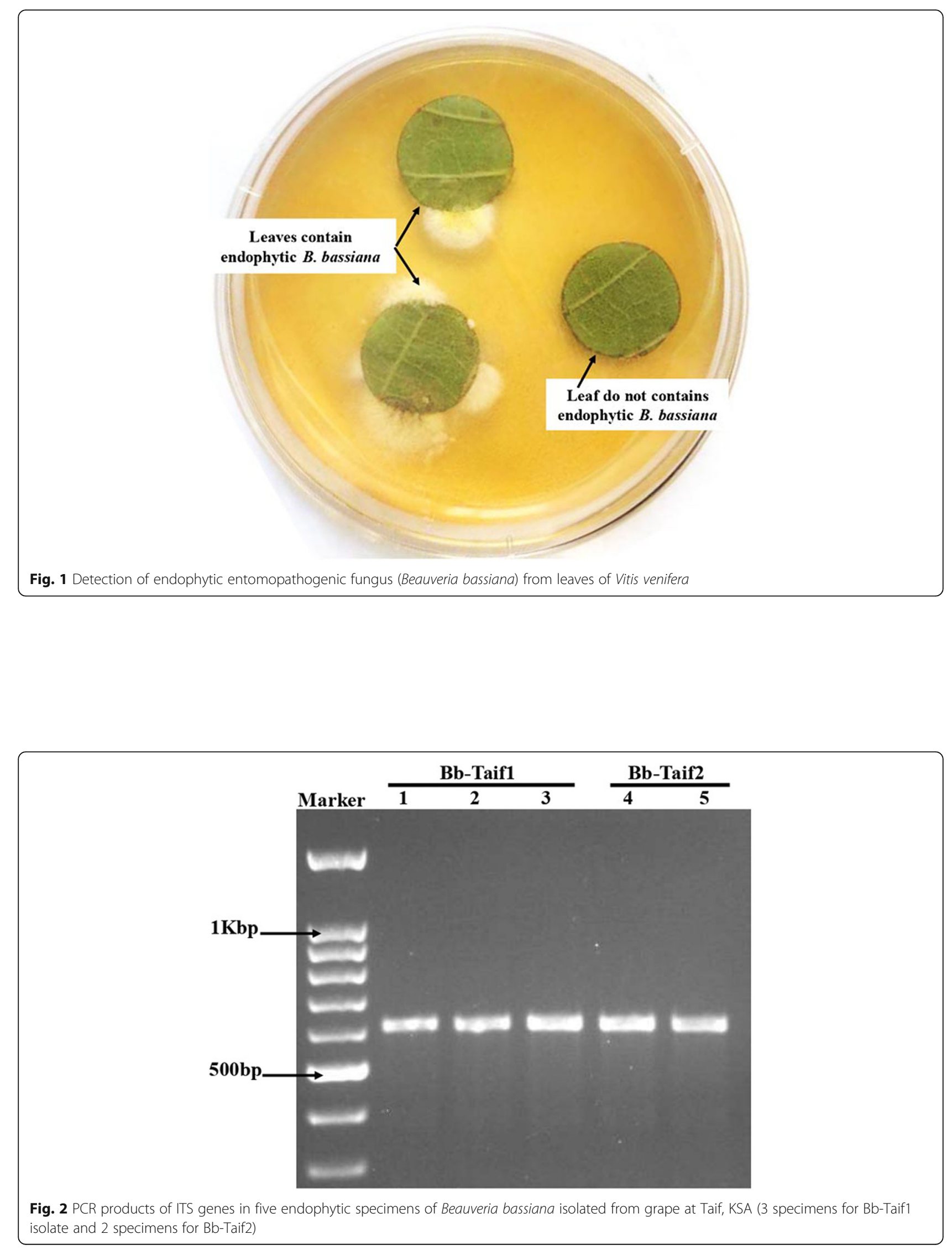


\begin{tabular}{|c|c|c|}
\hline $1>$ & GAAGTAAAAGTCGTAACAAGGTCTCCG & 60 \\
\hline Bb-Taif2> & 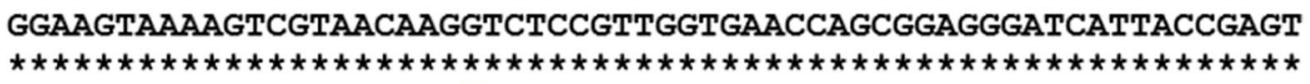 & 60 \\
\hline Bb-Taif1> & ГTСААСТСССТАAСССТTСTGTGAACCTACСTATCGTTGCTTCGGCGGACTCGCCCCAG & 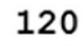 \\
\hline Bb-Taif2> & 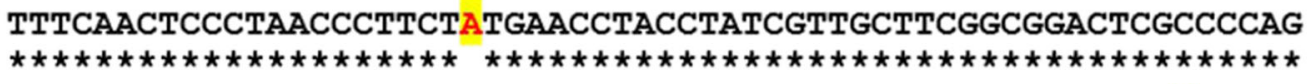 & 120 \\
\hline Bb-Taif1> & CCCGGACGCGGACTGGGCCGGCGGCCCGCCGGGGACCTCAAACTCTTGTATTCCAGCATC & \\
\hline Bb-Taif2> & 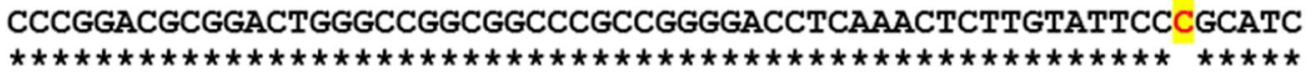 & 0 \\
\hline $\mathrm{Bb}-\mathrm{Taif1>}$ & TTCTGAATACGCCGCAAGGCAAAACAAATGAATCAAAACTTTCAACAACGGATCTCTTGG & 240 \\
\hline $\mathrm{Bb}-\mathrm{Taif2>}$ & 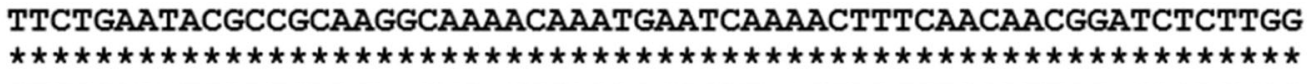 & 0 \\
\hline Bb-Taif1> & СTCTGGCATCGATGAAGAACGCAGCGAAACGCGATAAGTAATGTGAATTGCAGAATCCAG & \\
\hline if2> & 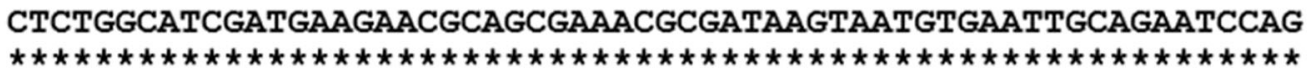 & \\
\hline $\mathrm{Bb}-\mathrm{T}$ & TGAATCATCGAATCTTTGAACGCACATTGCGCCCGCCAGCATTCTGGCGGGCATGCCTGT & \\
\hline f2> & 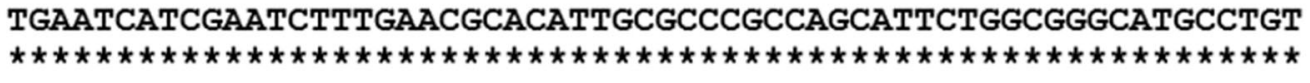 & \\
\hline if1> & TCGAGCGTCATTTCAACCCTCGACCTCCCСTTGGGGAGGTCGGCGTTGGGGACCGGCAGC & \\
\hline if2> & 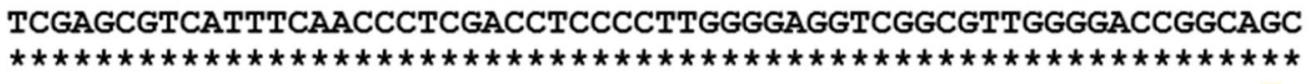 & \\
\hline 1> & ACACCGCCGGCCCTGAAATGGAGTGGCGGCCCGTCCGCGGCGACCTCTGCGCAGTAATAC & \\
\hline$f 2>$ & 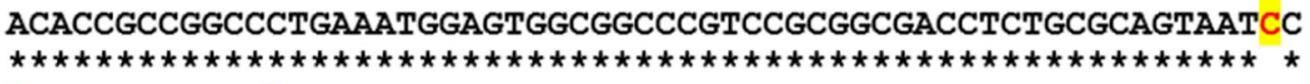 & \\
\hline $0-1$ & AGCTCGCACCGGGACCCCGACGCGGCCACGCCGTAAAACACCCAACTTCTGAACGTTGAC & \\
\hline if2> & 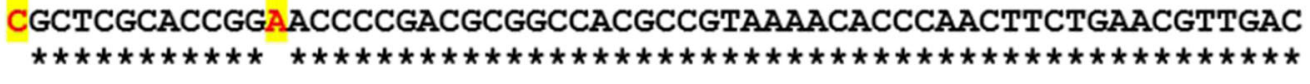 & \\
\hline & CTCGAATCAGGTAGGACTACC & \\
\hline $\mathrm{Bb}-\mathrm{t}$ & 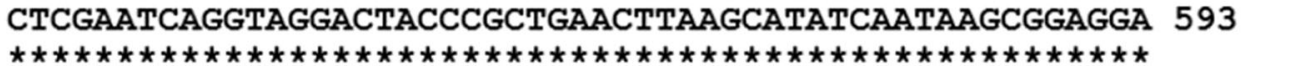 & \\
\hline
\end{tabular}

Fig. 3 Sequences of ITS region of 2 isolates of endophytic fungus, Beauveria bassiana with alignment of both. The single neoclutide polymorphism (SNP) with red and highlighted color while the sequence indicates genes as 18S-partial sequence (1-53), ITS1 (54-214), $5.8 S$ (215-371), ITS2 (372-534), and 28S-partial sequence (535-593)

establishment of $B$. bassiana in cassava plants (Greenfield et al. 2016). Also, grapevine inoculation trials via soil inoculation or root dipping resulted in endophytic colonization of B. bassiana but not at all plants (Rondot and Reineke 2018).

The values of $\mathrm{LC}_{50}$ and $\mathrm{LC}_{90}$ for the 2 tested isolates of endophytic $B$. bassiana against A. illinoisensis after 3 days of treatment are presented in Table 1 . The $\mathrm{LC}_{50}$ value of isolate Bb-Taif1 $\left(6.041 \times 10^{4}\right)$ was significantly lower than of isolate Bb-Taif2 $\left(3.199 \times 10^{5}\right.$ spores $\left./ \mathrm{ml}\right)(t=2.767$, $P=0.024)$. Also, there was a significant difference between the lowest bound of $95 \%$ confidence interval of $\mathrm{LC}_{50}$ values $(t=2.278, P=0.052)$, while this difference was significant in the upper bound $(t=3.476, P=0.008)$. The $\mathrm{LC}_{50}$ value of isolate Bb-Taif1 is compatible with Sayed et al. (2019) $\left(6.46 \times 10^{4}\right.$ spores $\left./ \mathrm{ml}\right)$ for an isolate, which was isolated from the soil at the same location. This finding, coupled with the molecular conformity, reinforce the previous

Table 1 Values of $L_{50}$ and $L_{90}$ with 95\% confidence intervals of the two tested endophytic isolates of Beauveria bassiana on grapevine aphid, Aphis illinoisensis

\begin{tabular}{|c|c|c|c|c|c|c|c|c|c|}
\hline \multirow[t]{3}{*}{ Isolates } & \multicolumn{3}{|c|}{$\mathrm{LC}_{50}$ (spores $/ \mathrm{ml}$ ) } & \multicolumn{3}{|c|}{$\mathrm{LC}_{\mathbf{9 0}}$ (spores $/ \mathrm{ml}$ ) } & \multirow[t]{3}{*}{ Intercept } & \multirow[t]{3}{*}{ Slope \pm SE } & \multirow[t]{3}{*}{$x^{2}$} \\
\hline & \multirow[t]{2}{*}{ Values } & \multicolumn{2}{|c|}{ 95\% confidence intervals } & \multirow[t]{2}{*}{ Values } & \multicolumn{2}{|c|}{ 95\% confidence intervals } & & & \\
\hline & & Lower bound & Upper bound & & Lower bound & Upper bound & & & \\
\hline Bb-Taif1 & $6.041 \times 10^{4}$ & $2.253 \times 10^{4}$ & $1.524 \times 10^{5}$ & $6.130 \times 10^{6}$ & $4.652 \times 10^{7}$ & $1.903 \times 10^{6}$ & -3.201 & $0.667 \pm 0.020$ & 9.5204 \\
\hline Bb-Taif2 & $3.199 \times 10^{5}$ & $1.708 \times 10^{5}$ & $6.044 \times 10^{5}$ & $7.474 \times 10^{7}$ & $4.367 \times 10^{8}$ & $2.783 \times 10^{7}$ & -3.081 & $0.562 \pm 0.025$ & 6.1148 \\
\hline Sig. & $*$ & NS & $* *$ & * & * & * & NS & * & NS \\
\hline
\end{tabular}

* (significant), ** (high significant), and NS (insignificant) with a $P=0.05$ 
opinion that the isolate from the soil is the same endophytic isolate in this study. On the other hand, the $\mathrm{LC}_{50}$ value of isolate 1 is in accordance with previous finding of $\mathrm{LC}_{50}$ value for different isolates of $B$. bassiana against different aphid species such as Selvaraj et al. (2012) $\left(1.5 \times 10^{4}\right.$ spores/ml to the aphid, Hyadaphis coriandri), Eidy et al. (2016) $\left(2.66 \times 10^{5}\right.$ spores $/ \mathrm{ml}$ against Macrosiphum rosae), Saranya et al. (2010) $\left(4.5 \times 10^{4}\right.$ spores $/ \mathrm{ml}$ against Aphis craccivora Koch.), and Nirmala et al. (2006) $\left(6.57 \times 10^{5}\right.$ spores/ml against Aphis gossypii Glov.). In general, the virulence of the same isolate of $B$. bassiana varied against different aphid species such as the findings of Akmal et al. (2013) who found that the $\mathrm{LC}_{50}$ values were $6.28 \times 10^{5}$ and $6.76 \times 10^{6}$ spores $/ \mathrm{ml}$ against Brevicoryne brassicae (Linn.) and Schizaphis graminum L., respectively.

On the same context of $\mathrm{LC}_{50}$, in the present study, the $\mathrm{LC}_{90}$ value of isolate $\mathrm{Bb}$-Taif1 $\left(6.13 \times 10^{6}\right.$ spores $\left./ \mathrm{ml}\right)$ was significantly lower than of the isolate Bb-Taif2 $\left(7.474 \times 10^{7}\right.$ spores $\left./ \mathrm{ml}\right)(t=2.739, P=0.025)$. Also, both of the lowest and highest bound of $95 \%$ confidence interval of $\mathrm{LC}_{90}$ values were differed significantly $(t=$ 2.332, $P=0.048$ and $t=3.075, P=0.015$, respectively). Meanwhile, the intercepts and $X^{2}$ were not differed significantly $(t=0.726, P=0.488$ and $t=1.072$, $P=0.315$, respectively), while the difference in slope was significant $(t=3.263, P=0.011)$.

Generally, the virulence of the 2 tested endophytic isolates indicated that the isolate $\mathrm{Bb}$-Taif1 was higher in its virulence than the Bb-Taif2 isolate. Moreover, the findings of molecular characteristic and the virulence in this study and the findings of Sayed et al. $(2018,2019)$ showed that the isolate (Bb-Taif1) is endemic in the soil and establishment in the grapevine tissues as an endophytic fungus.

\section{Conclusion}

Using the endophytic indigenous isolate of B. bassiana for controlling aphids in vineyards achieved a high mortality rate in aphids' populations. Also, the isolate (Bb-Taif1) could be used as conidia spraying, soil inoculation, and/or root immersion for grapevine plants. Further investigations are needed on this isolate for its efficacy on other piercing sucking or chewing insect pests.

\section{Abbreviations}

ITS1: Internal transcribed spacer-1; ITS2: Internal transcribed spacer-2; PCR: Polymerase chain reaction; PDA: Potato Dextrose Agar; $\mathrm{LC}_{50}$ : The median lethal concentration for a population; $\mathrm{LC}_{90}$ : Lethal concentration for $90 \%$ of a population

\section{Acknowledgements}

The authors would like to express their deepest thanks to High Altitude Research Center, Taif University, Saudi Arabia, for the financial support for the current research through a research grant number 1-440-6171.

\section{Authors' contributions}

All authors read and approved the final manuscript.
Funding

This study was financed by Taif University, Saudi Arabia, grant number $1-440-6171$

\section{Availability of data and materials}

All data generated or analyzed in this study are available in this published manuscript.

\section{Ethics approval and consent to participate}

Not applicable.

\section{Consent for publication}

This study does not contain any individual person's data.

\section{Competing interests}

The authors declare that they have no competing interests.

\section{Author details}

'Department of Biotechnology, Faculty of Science, Taif University, Taif 888, Saudi Arabia. ${ }^{2}$ Department of Economic Entomology and Pesticides, Faculty of Agriculture, Cairo University, Giza 12613, Egypt. ${ }^{3}$ High Altitude Research Center, Deanship of Scientific Research, Taif University, Taif 888, Saudi Arabia. ${ }^{4}$ Department of Genetics, Faculty of Agriculture, Alexandria University, Alexandria 21526, Egypt. ${ }^{5}$ Kafrelsheikh University, Kafr Elsheikh 33511, Egypt. ${ }^{6}$ Department of Biology, Faculty of Science, Taibah University, Medina, Saudi Arabia. 'Department of Biology, Faculty of Science, Taif University, Taif 888, Saudi Arabia.

Received: 20 January 2020 Accepted: 12 March 2020

Published online: 08 April 2020

\section{References}

Abbott WS (1925) A method of computing the effectiveness of an insecticide. Econ Entomol 18:265-267

Akmal M, Freed SH, Malik MN, Gul HT (2013) Efficacy of Beauveria bassiana (Deuteromycotina: Hypomycetes) against different aphid species under laboratory conditions. J Zool 45(1):71-78

Azevedo JL, Maccheroni W Jr, Pereira JO, Araújo WL (2000) Endophytic microorganisms: a review on insect control and recent advances on tropical plants. Electron J Biotechnol 3:40-65

Backman PA, Sikora RA (2008) Endophytes: an emerging tool for biological control. Biol Control 46:1-3

Batta YA (2018) Efficacy of two species of entomopathogenic fungi against the stored-grain pest, Sitophilus granarius L. (Curculionidae: Coleoptera), via oral ingestion. Egypt J Biol. Pest Control 28:44

Blackman RL, Eastop VF (2006) Aphids on the herbaceous plants and shrubs: the Natural History Museum. Wiley, New York

Cosoveanu A, Gimenez-Mariño C, Cabrera Y, Hernandez G, Cabrera R (2014) Endophytic fungi from grapevine cultivars in Canary Islands and their activity against phytopatogenic fungi. Int J Agric and Crop Sciences 7(15):1497-1503

Eidy M, Rafiee-Dastjerdi H, Zargarzadeh F, Golizadeh A, Mahdavi V (2016) Pathogenicity of the entomopathogenic fungi Beauveria bassiana (Balsamo) and Verticillium lecanii (Zimmerman) against aphid Macrosiphum rosae, Linnaeus (Hemiptera: Aphididae) under laboratory conditions. Jord J Biol Sciences 9(1):25-28

El-Gantiry AM, El-Heneidy AH, Mousa SF, Adly D (2012) Aphis illinoisensis Shimer (Hemiptera: Aphididae) a recent invasive aphid species in Egypt. Egypt J Biol Pest Control 22(2):225-226

Fahmi Al, Nagaty MA, El-Shehawi AM (2012) Fruit quality of Taif grape (Vitis vinifera L.) cultivars. J Am Sci 8(5):590-599

Gonzalez F, Tkaczuk C, Dinu MM, Fiedler Z, Vidal S, Zchori-Fein E, Messelink GJ (2016) New opportunities for the integration of microorganisms into biological pest control systems in greenhouse crops. J Pest Science 89(2): 295-311

Greenfield M, Gómez-Jiménez MI, Ortiz V, Vega FE, Kramer M, Parsa S (2016) Beauveria bassiana and Metarhizium anisopliae endophytically colonize cassava roots following soil drench inoculation. Biol Control 95:40-48

Humber RA (1997) Chapter V-1 - Fungi: identification. In: Lawrence AL (ed) Manual of Techniques in Insect Pathology. Academic Press, London, pp 153-185 
Jaber $L$ (2015) Grapevine leaf tissue colonization by the fungal entomopathogen Beauveria bassiana s.l. and its effect against downy mildew. BioControl 60: 103-112

Klieber J, Reineke A (2016) The entomopathogen Beauveria bassiana has epiphytic and endophytic activity against the tomato leaf miner Tuta absoluta. J App Entomol 140:580-589

Lacey LA, Grzywacz D, Shapiro Ilan DI, Frutos R, Brownbridge M, Goettel MS (2015) Insect pathogens as biological control agents: back to the future. Invertebr Pathol 132:1-41

Martini M, Musetti R, Grisan S, Polizzotto R, Borselli S, Pavan F, Osler R (2009) DNA-dependent detection of the grapevine fungal endophytes Aureobasidium pullulans and Epicoccum nigrum. Plant Dis 93:993-998

McKinnon AC, Saari S, Moran-Diez ME, Meyling NV, Raad M, Glare TR (2017) Beauveria bassiana as an endophyte: a critical review on associated methodology and biocontrol potential. BioControl 62(1):1-17

Mondal S, Baksi S (2018) Strain-specific identification of Beauveria bassiana isolated from a novel habitat, using rDNA-based sequence analogy. Egypt J Biol Pest Control. 28:29

Nirmala R, Ramanujan B, Rabindra RJ, Rao NS (2006) Effect of entomofungal pathogens on mortality of three aphid species. J Biol Control 20:89-94

Pacifico D, Squartini A, Crucitti D, Barizza E, Lo Schiavo F, Muresu R, Carimi F, Zottini M (2019) The role of the endophytic microbiome in the grapevine response to environmental triggers. Front Plant Sci 10:1256. https://doi.org/ 10.3389/fpls.2019.01256

Pfeiffer DG, Schultz PB (1986) Major insect and mite pests of grape in Virginia. In: Virginia Cooperative Extension Service Bulletin, pp 444-567

Rai M, Rathod D, Agarkar G, Dar M, Brestic M, Pastore GM, Junior MR (2014) Fungal growth promoter endophytes: a pragmatic approach towards sustainable food and agriculture. Symbiosis 62:63-79

Rehner SA, Posada F, Buckley EP, Infante F, Castrillo A, Vega FE (2006) Phylogenetic origins of African and Neotropical Beauveria bassiana s.l pathogens of the coffee berry borer, Hypothenemus hampei. J Invertebr Pathol 93:11-21

Rondot Y, Reineke A (2018) Endophytic Beauveria bassiana in grapevine Vitis vinifera (L.) reduces infestation with piercing-sucking insects. Biol Control 116: 82-89

Saikkonen K, Saari S, Helander M (2010) Defensive mutualism between plants and endophytic fungi? Fungal Divers 41:101-113

Saranya S, Ushakumari R, Jacob S, Philip BM (2010) Efficacy of different entomopathogenic fungi against cowpea aphid, Aphis craccivora (Koch). J Biopest 3(1):138-142

Sayed SM, Ali EF, Al-Otaibi SS $(2019,29)$ Efficacy of indigenous entomopathogenic fungus, Beauveria bassiana (Balsamo) Vuillemin, isolates against the rose aphid, Macrosiphum rosae L. (Hemiptera: Aphididae) in rose production. Egypt J Biol Pest Control 19

Sayed SM, Ali EF, El-Arnaouty SA, Mahmoud SF, Amer SA (2018) Isolation, identification and molecular diversity of indigenous isolates of Beauveria bassiana from Taif region, Suadi Arabia. Egypt J Biol Pest Control. 28:47

Selvaraj K, Kaushik HD, Gulati R (2012) Evaluation of Beauveria bassiana (Balsamo) Vuillemin against coriander aphid, Hyadaphis coriandri (Das) (Aphididae: Homoptera). J Biol Control 26(1):55-58

Shin TY, Choi J, Bae S, Koo H, Woo S (2010) Industrial Entomology. Study on selective media for isolation of entomopathogenic fungi. Int J Indust Entomol 20:7-12

SPSS (2015) Version 23.0 for Windows User's Guide, Chicago

Strobel GA, Daisy B, Castillo U, Harper J (2004) Natural products from endophytic microorganisms. J Nat Prod 67:257-268

Suryanarayanan TS (2013) Endophyte research: going beyond isolation and metabolite documentation. Fungal Ecol 6:561-568

Unterseher M, Petzold A, Schnittler M (2012) Xerotolerant foliar endophytic fungi of Populus euphratica from the Tarim River basin, Central China are conspecific to endophytic ITS phylotypes of Populus tremula from temperate Europe. Fungal Divers 54:133-142

Vega FE (2008) Insect pathology and fungal endophytes. J Invertebr Pathol 98: $277-279$

Vega FE (2018) The use of entomopathogens as endophytes in biological control: a review. Mycologia 110(1):4-30

Vidal S, Jaber LR (2015) Entomopathogenic fungi as endophytes: plantendophyte-herbivore interactions and prospects for use in biological control. Current Sci 109:46-54
Wani ZA, Ashraf N, Mohiuddin T, Riyaz-Ul-Hassan S (2015) Plant-endophyte symbiosis, an ecological perspective. Appl Microbiol Biotechnol 99:2955-2965

Yang MZ, Ma MD, Yuan MQ, Huang ZY, Yang WX, Zhang HB et al (2016) Fungal endophytesas a metabolic fine-tuning regulator for wine grape. PLoS One 11(9):e0163186. https://doi.org/10.1371/journal.pone.0163186

Zimmermann G (2007) Review on safety of the entomopathogenic fungi Beauveria bassiana and Beauveria brongniartii. Biocont Sci Technol 17:553-596

\section{Publisher's Note}

Springer Nature remains neutral with regard to jurisdictional claims in published maps and institutional affiliations.

\section{Submit your manuscript to a SpringerOpen ${ }^{\circ}$ journal and benefit from:}

- Convenient online submission

- Rigorous peer review

- Open access: articles freely available online

High visibility within the field

- Retaining the copyright to your article

Submit your next manuscript at $\boldsymbol{\nabla}$ springeropen.com 